\title{
Factors Critical in Marketing Strategies of
}

\section{Insurance Companies in Saudi Arabia}

\author{
Abdalelah S. Saaty \\ Dean, College of Business -Rabigh, King Abdulaziz University, Saudi Arabia \\ E-mail: assaati@gmail.com \\ Zaid Ahmad Ansari \\ Assistant Professor (Marketing), Head, Department of Marketing \\ College of Business - Rabigh, King Abdulaziz University, Saudi Arabia \\ E-mail: zaid.ahmad@rediffmail.com
}

Received: Feburary 21, $2011 \quad$ Accepted: April 8, $2011 \quad$ doi:10.5539/ijms.v3n3p104

\begin{abstract}
This paper attempts to find out the factors important in developing a suitable marketing strategy for insurance companies in Saudi Arabia. It investigates the reasons for buying insurance by the current users of insurance, reasons for not buying insurance by non-users of insurance and the issues and problems faced by Saudi Insurance industry.

The study is based primarily on primary data collected randomly from 500 users of insurance, from 400 non-users of insurance and 80 insurance executives through structured questionnaire in Jeddah city of Saudi Arabia. The three questionnaires were developed in English and translated into Arabic for effective response due to Saudi Culture, and language. The response from the three groups of respondents were analyzed using simple statistical techniques such as percentages, mean, chi-square tests, factor analysis, and ANOVA analysis with the help of Statistical Package for the Social Sciences (SPSS).

The results of the study show that the social and regulatory factors played crucial role in the consumer's decision in purchasing insurance. However it was also found that the public at large is unaware about the benefits of insurance, and various types of insurance products. The insurance companies shall focus of promotional marketing strategies. The marketer's primary focus should be on promotional activities.
\end{abstract}

Keywords: Marketing, Sharia'h, Insurance, Saudi Arabia

\section{Introduction}

Insurance market activity, both as a financial intermediary and as a provider of risk transfer and indemnification, promotes economic growth by allowing different risks to be managed more efficiently. This activity would encourage the accumulation of new capital and mobilize domestic savings into productive investments. Arena (2008), found that a robust causal relationship exists between insurance market activities and economic growth.

Insurance activity may contribute to economic growth by improving the financial system functions, both as a provider of risk transfer and indemnification and as an institutional investor, in the following ways: (i). Promoting financial stability, (ii). Facilitating trade and commerce (the most ancient insurance activity), (iii). Allowing different risks to be managed more efficiently by encouraging the accumulation of new capital, (iv). Mobilizing domestic savings, (v). Fostering a more efficient allocation of domestic capital, and (vi). Helping to reduce or mitigate losses (Skipper, 1997).

The developed economies such as USA and Japan etc. and developing economies like India and China were benefitting from the insurance system, but countries like Saudi Arabia were not. However, the Saudi Arabian government liberalized the insurance industry for private companies in 2004. Since then insurance industry is growing by leaps and bounds, but unfortunately this high growth is confined to compulsory lines of business i.e., motor insurance, and health insurance (for expatriates). These two lines of business contributed more than $70 \%$ of the total Gross Written Premium in 2009 (The Saudi Insurance Market Report, 2009). In this study the 
researcher wants to investigate the Saudi insurance industry from consumer's perspective to find out the factors which may be the motivating or demotivating the people of Saudi Arabia in buying insurance. The findings will help in extracting strong motivating and demotivating factors which shall be further used for suggesting an appropriate marketing strategy for the insurance companies in Saudi Arabia. Thus the objective of this study is to provide the insurance companies operating in Saudi Arabia with the factors they should focus on in developing a marketing strategy.

The marketing concept emerged in the mid-1950s. Instead of a product-centered, 'make-and-sell' philosophy the business shifted to a customer-centered, "sense-and-respond" philosophy. The job is not to find the right customers for your products, but to find the right products for the customers (Kotler and Keller, 2008).

The American Marketing Association, defined marketing as "An organizational function and set of processes for creating, communicating, and delivering value to customers and for managing customer relationships in ways that benefit the organization and its stakeholders". Marketing management is the art and science of choosing target markets and getting, keeping, and growing customers by creating, delivering, and communicating superior customer value. Thus in line with the above definition the researchers intend to extract from the response of the users of insurance, non users of insurance and executives of insurance companies in Saudi Arabia; such factors which need meticulous consideration for serving the Saudi people.

In the following section the researcher presents the current state of insurance in Saudi Arabia followed by a review of existing related literature, conceptual framework of the research and formation of hypothesis, research methodology, results and discussion, and conclusion and practical implications of the study.

\section{Synoptic view of the insurance industry in Saudi Arabia}

The insurance industry in Saudi Arabia was liberalized in the year 2004. This newly liberalized industry has been growing fast, the growth rate was $27 \%$ in 2008, and 33.8\% in 2009 (The Saudi Insurance Market Report, 2009). The growth is mainly driven by compulsory lines of business i.e., Motor Insurance and Health Insurance for expatriates. Health Insurance Gross Written Premiums represented $50 \%$ of the insurance market with a remarkable growth rate of $51.8 \%$ in 2009 . General insurance represented $43 \%$ of the total insurance market with an average growth rate of $14.4 \%$ and Protection and savings insurance market was $7 \%$ establishing very high growth rate of $68.9 \%$ in 2009 . It is note worthy that motor insurance within the category of general insurance represents $21 \%$ of the total insurance market of Saudi Arabia. Thus the motor insurance and health insurance business in Saudi Arabia makes more than 70\% of the total insurance market (The Saudi Insurance Market Report, 2009).

Insurance penetration defined as Gross Written Premiums (GWP) divided by the total Gross Domestic Product (GDP) in 2009 increased to $1.06 \%$ up from $0.62 \%$ in 2008 , representing a $69.9 \%$ increase. Insurance density defined as Gross Written Premiums per capita increased from SR440 per capita in 2008 to SR 576 per Capita representing a 30.8\% increase (The Saudi Insurance Market Report, 2009). Despite the high growth in insurance penetration, the total penetration level is incomparably low to the developed countries such as US and Japan. One of the most unpopular lines of business for Insurance in Saudi Arabia is Protection and Savings (P\&S). Interestingly this segment has shown high growth rate of $81 \%$ in 2008 and approximately $69 \%$ in 2009 (The Saudi Insurance Market Report, 2009). However, the researchers hypothesize that this remarkable growth in Protection and Savings may have happened due to the customers change in perception about the insurance by using compulsory insurance such as motor and health insurance. Thus they stepped out of these compulsory insurance to purchase Protection and Savings, which may further extend to other personal lines of insurance provided the insurance companies use appropriate marketing strategies.

Since 2004 the Saudi insurance industry has been growing on an average of more than $30 \%$ annually (The Saudi Insurance Market Report, 2009). But $71 \%$ of the total GWP is contributed by compulsory lines of insurance only showing the domination of the legal factors in Saudi Arabian insurance industry. However after six years of liberalization it is considered appropriate to investigate the Saudi people on different aspects of insurance such as enquiring public view on issues related to insurance in Saudi Arabia, reasons for purchasing insurance by the users of insurance, reasons for not purchasing insurance by the non users of insurance, idea of an ideal insurance plan from customers point of view. Besides the study also investigates from the current executives of insurance companies, the problems faced in marketing insurance products, which insurance people generally purchase, the dominating reason for purchasing insurance, what according to them shall be the focus in the insurance companies' advertising and promotion. The industry is apparently ready for second generation reforms, prior to it, is appropriate to conduct research to find the perception of people which is expected to have positively changed in favor of insurance by the use of compulsory lines of insurance evident from high growth rate in Protections and Savings insurance during 2008, and 2009. This study is important because the market potential will saturate soon 
with the coverage of compulsory lines of business i.e., Motor and Health Insurance. Thus, to promote other lines of insurance business it is important to know the mind-set of public about insurance to develop a marketing strategy which will help in increasing the insurance penetration and insurance density which is abysmally low compared other developed and developing countries. In the following section the researchers present the existing related literatures done by prominent scholars over the period of time across the world.

\section{Review of Literature}

Marketing is a societal process by which individuals and groups obtain what they need and through creating, offering, and freely exchanging products and services of value with others. Holistic marketing approach recognizes that 'everything matters' in marketing. It has four components i.e., Relationship marketing, Integrated marketing, Internal marketing and Performance marketing (Kotler and Keller 2008). McCarthy (2002) classified marketing activities as marketing mix tools of four broad kinds which he called four Ps of marketing: viz., product, price, place and promotion usually applied to marketing of tangible goods.

However to capture the distinctive nature of service performances three more elements associated with service delivery are considered physical environment, process, and people (Lovelock and Wirtz 2004). Thus, for effective marketing strategies of services all the seven P's (product, price, place, promotion, physical environment, process and people) play an important role.

In this paper the researchers analyzed the situation for each element of marketing mix for insurance industry in Saudi Arabia. The analysis would suggest the areas critical for developing effective marketing strategies by the insurance companies.

The following section discusses the existing related literature. Hussels S. (2005) identified the determinants that encourage insurance demand as (i) economic, (ii) political/legal, and (iii) social factors; he concluded that these factors affect the demand for insurance, life as well as property and casualty.

Economic factors: Relation between income and life insurance consumption has been confirmed by the cross country studies of Beenstock et al. (1986), Truett and Truett (1990), Browne and Kim (1993), and Outreville (1996). Beenstock et al. (1988), indicate that a positive relationship exists between national income in industrialized countries and spending on property-liability insurance.

Legal and Political factors: La Porta et al. $(1997,2000)$ and Levine $(1998,1999)$ show that legal environments which provide good investor protection tend to encourage a higher degree of financial intermediation as well as economic growth. Levine et al. (2000) highlights that countries with better creditors' rights, more rigorous law enforcement and better accounting information tend to have more highly developed financial intermediaries. This is particularly relevant to the insurance industry where consumers can be at the risk of opportunistic behaviour by insurance companies. For example, this could include companies refusing to pay claims, or alternatively reducing the investment returns due on a policy.

Ward and Zurbruegg (2002) examined the impact of legal and political determinants on life insurance consumption within Asia and OECD countries. They highlighted that in Asia an improvement in the legal system has a significant and positive impact on life insurance demand, with a $10 \%$ improvement in the functioning of the legal system generating a 5.5\% increase in life insurance demand. An improvement in the legal system here would relate to better enforcement and legal representation for individuals.

Social factors: Insurance can also be seen as a product that is valued subjectively by its customer. In fact, Hofstede (1995) points out that the level of insurance within an economy depends on the national culture and the willingness of individuals to use insurance as a means of dealing with risk. Douglas and Wildavsky (1982) show that the demand for life insurance in a country may be affected by the unique culture of the country to the extent that culture affects the degree of risk aversion. Using education and the uncertainty avoidance index to approximate levels of risk aversion, Esho et al. (2004) confirms that risk aversion has a significant impact on demand for property-casualty insurance.

Another social aspect analyzed by Zelizer (1979) is religion. He noted that historically religion has provided a strong source of cultural opposition to life insurance with some religious groups believing that a reliance on insurance represents a distrust of God's protective care. In some Muslim dominated countries, the religious beliefs inhibit those forms of insurance that facilitate speculation of future events, thereby discouraging growth of the insurance sector. Wasaw and Hill (1986), Browne and Kim (1993), Ward and Zurbruegg (2002) test whether countries with strong Islamic background have reduced demand for life insurance consumption. Their result generally do confirm that consumers in Islamic nations purchase less life insurance policies, which is 
reflected in the below global average life insurance penetration in Muslim dominated countries, such as the United Arab Emirates, Qatar, Kuwait and Saudi Arabia.

The foregoing study highlighted the importance of the existence of a dynamic and well functioning insurance industry for the growth of an economy. The existing literature shows that the demand for various types of insurance is affected by number of factors such as income and life insurance consumption. There is a relation between national income and spending on property-liability insurance, between legal environment and demand for insurance, national culture and the willingness of individuals to use insurance. Besides, risk aversion has significant impact on the demand for property casualty insurance. Education promotes an understanding of risk and hence aids insurance demand.

The study presents a synoptic view of the insurance industry in Saudi Arabia and shows that the Saudi insurance industry is dominated by compulsory lines of business i.e., motor insurance and health insurance for expatriates. In the present study, the researchers investigated the legal, economic and social factors from customer's perspective at a micro level such as impact of legal compulsion on purchase decision, how much the personal safety, safety and security of family were considered while purchasing insurance. Another important aspect investigated was whether insurance was purchased for return on investment or risk management? And the problems faced by the insurance executives in marketing insurance. The following sections present the conceptual framework of the study, research hypothesis, and the research methodology followed by results and discussions.

\section{Conceptual Framework of the Study}

The conceptual framework of the study is based on the review of existing related literature and secondary data on Saudi Insurance market. The study shows that the insurance market in Saudi Arabia is mainly dominated by compulsory lines of business i.e., motor insurance and health insurance (for expatriates). Therefore in this study the researcher analyzed the reasons for purchasing insurance by the users of insurance and their view on various issues related to insurance in Saudi Arabia. The researcher investigates the affect of Islamic principles on demand for insurance, problems faced by the insurance executives and the issues pertaining to Saudi insurance industry. Therefore the researchers propose the following hypothesis to be tested in this study.

\section{Hypothesis}

From the review of literature the researchers propose the following eleven hypotheses o be tested in this study. The results will thereafter will be used for discussion and suggesting marketing strategies for insurance companies in Saudi Arabia.

H1 : The Saudi insurance market is dominated by the compulsory insurance.

H2 : Legal compulsion is the main reason for purchasing insurance.

H3 : Level of education affects the perception of the users for insurance.

H4 : The age of the users affects the perception of the users of insurance.

H5 : People of Saudi Arabia prefer investment income to risk minimization.

H6 : Users of insurance are not satisfied with the insurance policies they used.

H7 : Islamic principles affect the demand for insurance in Saudi Arabia.

H8 : People do not know about the insurance in general.

H9 : People do not know about the insurance products.

H10 : Available insurance product range in Saudi insurance market is sufficient.

H11 : Level of existing insurance promotion by insurance companies is enough.

\section{Methodology and Data Collection}

\subsection{Data collection}

This study targets the insurance market of Saudi Arabia. The study was conducted on the users of insurance, non users of insurance and executives of insurance companies through structured questionnaires originally developed in English but translated into Arabic to fit the culture and language of Saudi Arabia. The study was proposed on a sample of 500 users of insurance, 500 non users of insurance and 100 executives. Approximately $20 \%$ more questionnaires were distributed for all the three groups of respondents i.e., 600 questionnaires were distributed for users and non users and 120 questionnaires were distributed for executives of the insurance companies. The questionnaires were distributed by trained undergraduate students randomly in Jeddah city. 500 usable 
questionnaires were collected back from the users and 400 from the non users. From the executives 80 usable questionnaires were received. The collected information through questionnaires was entered in SPSS software for analysis.

\subsection{Survey Instrument}

Questionnaires were used for the purpose of data collection from each group of respondent i.e., users of insurance, non users of insurance and insurance executives. The user's questionnaire enquired about the reasons for purchasing insurance and the issues pertaining to insurance in Saudi Arabia from customer's point of view. The same enquiry was done from the executives as well, however the non users were asked to tell the reason why they didn't purchase insurance. This was to find out what insurance the people of Saudi Arabia generally purchase and make comparative analysis of the responses from users and the executive's response. For effective administration the questionnaire was translated into Arabic.

\subsection{Data Analysis}

The data was analyzed on SPSS software by using the following statistical tools: percentage analysis, mean, factor analysis, and cluster analysis.

\section{Results and Discussion}

\subsection{Results}

This section presents the results of the study. Table 1, shows the profile of the respondents. The respondents were grouped into different age groups as follows: first group 20-29 years, second group 30-39 and the third group was in the range of 40-60 years. On the education basis they were grouped as completed high school, undergraduates, graduates, and diploma. The following section presents the profile of users and non users of insurance in Saudi Arabia.

Users of insurance: $80 \%$ of the users of insurance were from the age group of $20-29$ years, $17.2 \%$ were between $30-39$, and $2.9 \%$ were 40 and above. $47.8 \%$ users were high school, $12.4 \%$ were undergraduates, $17.2 \%$ were graduates and $22.6 \%$ were having diploma certificates.

Non users of insurance: $73 \%$ of the non users were between $20-29$ years, $24 \%$ were between $30-39$ years and $3 \%$ were above 40 years. From the total respondents 55\% respondents completed their high school, 16\% were undergraduates, $9.5 \%$ were graduates and $19.5 \%$ had a diploma.

Age and health insurance analysis: In table 2, the consumer's response on purchase of health insurance is presented. Approximately $60 \%$ users purchased health insurance and of the users who purchased health insurance, $81.3 \%$ of them were in the age group of $20-29,14.1 \%$ in $30-39$ years and $4.6 \%$ in the age group of 40-60 years. It is very interesting to know that the entire 14 respondent in the age group of 40-60 years purchased the health insurance.

From 400 respondents in first age group (20-29 years), 247 purchased health insurance, from 86 respondents, in the second age group (30-39 years), 43 purchased health insurance, and from the third group (40-60 years), all of the 14 respondents purchased the health insurance. Thus the young generations have shown interest in purchasing health insurance as well as the all the people aged 40 years and above have purchased the health insurance. As is shown by the chi-square $\left(\chi^{2}=13.387\right.$, Sig. 0.001$)$ value the users differ significantly in the different age group.

Education and health insurance analysis: Table 2, further presents the education profile of the users of insurance and their response vis-à-vis, health insurance. Approximately, $47 \%$ of the respondents had completed high school, $12.4 \%$ were under graduate, $17.2 \%$ had done master and $22.6 \%$ were holding diplomas. The chi-square value $\left(\chi^{2}=2.196\right.$, Sig. $\left.=0.533\right)$ showed that there is no significant effect of education on purchase decision of insurance consumers in Saudi Arabia.

Motor insurance: $62 \%$ of the users purchased motor insurance. Despite the fact that the Motor insurance is compulsory in Saudi Arabia for all only 62\% purchased it. Within the respondents' age group 30-39, majority purchased motor insurance. Chi-square values show that age and education both have both have significant effect on the purchase of motor insurance, acceptable at $95 \%$ confidence level.

Hypothesis 1: The Saudi insurance market is dominated by the compulsory lines of insurance in Saudi Arabia.

Table 2 and 3 show that $61 \%$ of the respondents purchased health insurance and $62 \%$ of the respondents purchased motor insurance policies. This fact is supported by the secondary data as well that the insurance 
market in Saudi Arabia is dominated by health insurance and motor insurance. In 2009, 70\% of the total Gross Written Premiums were contributed by health insurance and motor insurance alone (The Saudi Insurance Market Report, 2009). Thus, the hypothesis 1 is true and it can be accepted that the Saudi insurance market is dominated by compulsory lines of business.

\section{Hypothesis 2: Legal compulsion is an important reason for purchasing insurance.}

Table 4 and 5 present the different aspects of insurance across educational and age categories. One of the aspects investigated in it is the reason for purchasing insurance. There were four options given to the respondents to select i.e., legal compulsion, personal safety and security, safety and security of the family and good return on investment. $75.4 \%$ of the respondents said that they purchased insurance because it is compulsory and approximately $23 \%$ said that they purchased it for personal safety and security. Other two reasons did not play any significant role in motivating the users to purchase insurance. Thus, it can safely be said that legal compulsion is an important reason in motivating the users in purchasing insurance, hence hypothesis 2 is accepted.

\section{Hypothesis 3: Level of education affects the perception of the users for insurance.}

The researcher analyzed the perception of the users of insurance vis-à-vis education and their age. The effect of education and age was analyzed vis-a-vis payment of amount premium, and perception of premium as low, medium, and high, reason for purchasing insurance, source of purchasing insurance, and level of risk coverage. Table 4, shows the perception of users on the above said aspects and the affect of education on these aspects. It shows that the perception of the users for the given different aspects of insurance is significantly affected by the education level of the users. The chi-square value indicates that in all the above cases education has significant effect accepted at $95 \%$ confidence level. The table shows that only $21.4 \%$ of the respondents paid SR500 and less and $80 \%$ paid more than SR 500 . The premium paid is perceived medium by $46.2 \%$ and low by $13.2 \%$. The driving force for the purchase of insurance was the legal compulsion. Despite the fact that most of the respondents purchased insurance to comply with law (75.4\%), they purchased full coverage $56.8 \%$, paying high premium. Personal security is another important reason for purchase of insurance. $22.8 \%$ purchased insurance for the security of the family. Which may be said to be the changing attitude of public towards insurance moving from compulsory reasons to personal security, which may extend to the other reasons in future such as security of family and return on investment. Thus the education has its impact on the perception of the users for insurance; hence hypothesis 3 is true and accepted.

\section{Hypothesis 4: The age of the users affects the perception of the users of insurance.}

Table 5, analyzes the said aspects across the different age group. The study focuses on the effect of the age of the respondents on their perception about insurance. The perception of the customers for various aspects of insurance is significantly different across the different age groups. According to the age of the respondents their attitude and behaviour significantly vary. It is interesting to note that $80 \%$ of the respondents are young from the age group of $20-39.17 .2 \%$ are in the age group of 30-39 and only $2.8 \%$ above 40 years. However, the three age groups significantly differ in their premium payment, perception of premium paid, reason for purchase of insurance and the level of coverage. People above 40 years paid higher premium though they perceive it to be high and medium and they purchase insurance because it is mandatory $(50 \%)$ and $50 \%$ purchase it for their personal security. They all purchase it directly from the insurance company. All $(100 \%)$ of the respondents got full coverage for their risks. It (table 5) further shows that the younger group purchased insurance mainly to comply with the law (77.3\%). Thus from the foregoing discussion it is evident that perception of the user is significantly different across age groups and thus the hypothesis 4 is accepted.

\section{Hypothesis 5: People of Saudi Arabia prefer investment income to risk minimization.}

From the important aspects of an ideal insurance product, factor analysis was conducted to identify the underlying dimensions among a set of insurance product attributes, (table 6). Principal Component Analysis was done using varimax rotation criterion. The Kaiser criterion was used to retain only those factors with Eigen values greater than 1. Based on factor analysis, two sets of components/ factors emerged with an Eigen value greater than 1, which explains the $61.537 \%$ of variance. The total variance explained by factor 1 is $39.168 \%$, primarily comprising the attributes related to risk management abilities of an insurance product as indicated by factor loading values. Factor 2 explains $22.369 \%$ variation and loads high on factors related to high return of investment.

In table 7, Hierarchical Clustering approach has been used to group the consumers into market segments based on their responses on product attributes. The consumers have been divided into two segments. The segment 1, 
which comprised of $77.4 \%$ (table 7) of the sample, prefer insurance product for getting higher return on the investment. This provides a clear indication that the insurance providers should not only focus on the risk coverage attributes of their products, but they should emphasise much on the return on investment. The consumers belonging to segment 2 focuses much on the risk coverage and claims settlements. Thus the investment return is preferred than the risk coverage and risk minimization. Therefore the hypothesis 5 is true and accepted.

\section{Hypothesis 6: Users of insurance are not satisfied with the insurance policies they used.}

Table 9, presents the satisfaction level of the users of motor and health insurance for various aspects of insurance such as product features, premium rate, payment of premium, risk coverage, promotion and discount, procedures of purchasing insurance, level of hidden information and claim settlement procedure. The users of both the insurance policies i.e., motor insurance, and health insurance are by and large satisfied shown by the mean value less than 2.5. However the users of motor insurance are seem to be less satisfied by the promotion and discounts and claim settlement procedures of the insurance companies. The users of health insurance are comparatively more satisfied than the users of motor insurance as shown by the lower mean values. Thus the hypothesis 6 is rejected which states that the users are not satisfied.

\section{Hypothesis 7: Islamic principles affect the demand for insurance in Saudi Arabia.}

The affect of sharia'h on purchase decision of the people of Saudi Arabia has been analyzed from all the three groups of the respondent's viz., users of insurance, non users of insurance, and executives of insurance companies. In table 10, the users and executives emphasized that the insurance companies must focus on educating the people that insurance in Saudi Arabia is Sharia'h compliant. In fact the users from among other factors placed this factor as most important (mean value 1.26, Std. deviation 0.439 ) and the executives placed it at third place (mean 1.73, std. deviation 0.449).

In table 11, regarding the issues in respect to insurance, from the given eight factors agreed that people in Saudi Arabia consider that Insurance in Saudi Arabia is against Sharia'h. On five point scale where 1 equal highly agree to 5 highly disagree, the factor stating that 'people in Saudi Arabia consider insurance against Sharia'h' was with the lowest mean (mean 1.67, std. deviation 1.128) indicating that users agree to the fact that this is one of the strongest resistant the Saudi Insurance industry is facing.

Again in table 12, the same factor was investigated from the non users of insurance. They also agreed that the reason for not purchasing insurance was that they consider insurance against Sharia'h. In table 13, on three points scale 1 equal to very important to 3 equal to important, the non users again emphasized that they want Sharia'h compliant insurance plan (mean 1.39, std. deviation 0.642).

Finally the executives where investigated to tell the problems of marketing faced insurance policies in Saudi Arabia (table 17). They confirmed the fact that the people of Saudi Arabia are hesitant in purchasing insurance because they consider insurance against Sharia'h. To get broader and deeper view the executives where categorized in to three groups viz., Salesman, Marketing executives and other executives of the insurance companies. The entire three groups agree to this fact however there was difference among the three groups (F3.164, Sig. 0.048). Thus the hypothesis 7, stating that Islamic principles affect the demand for insurance Saudi Arabia is true and accepted.

\section{Hypothesis 8: People do not know about the insurance in general.}

The above hypothesis has been verified from table no. 11, 12 and 17. Table 11, presents the issues in respect to insurance from users point of view. On five point scale from 1 highly agree to 5 highly disagree, the mean value 2.45 for the factor 'people do not know about insurance' shows that they do not agree to the fact that people in Saudi Arabia do not know about insurance in general. In table 12 the non users of insurance further said that they are aware of insurance and may buy the same in future. The non users placed the factor "not fully aware of insurance plans' second last among the given eight factors. And finally the executives in table 17, presenting the problems of marketing on 2 point scale, 1 equal to yes and 2 equal to no confirmed the fact that people of Saudi Arabia know about insurance in general. The mean value of 1.30 on 2 points scale is more towards confirmation, though it may not be considered very strong. Thus from the three groups of respondents do not agree to the fact that people of Saudi Arabia do not know about insurance in general, therefore hypothesis 8 is rejected.

\section{Hypothesis 9: People do not know about the insurance products.}

Table 10, analyses the users and executives view on the focus of the company. The users suggested that the insurance companies should focus on educating the people about the insurance products. Further in table 11, the users agreed to the fact that the people of Saudi Arabia do not know about insurance products (mean 2.09, Std. 
deviation 1.283). In table 19, the executives from among the other given factors highly supported the fact that people of Saudi Arabia do not know about different insurance products (mean 1.25, std. deviation 0.436, F 2.736, Sig. 0.071). All the three within the executives group i.e., salesman, marketing executive and other executives agreed to this fact.

\section{Hypothesis 10: Available insurance product range in Saudi insurance market is sufficient.}

In table 15 , approximately $54 \%$ of the executives said that the available product range of insurance in Saudi Arabia is enough. However the three sub groups within the executives significantly differed in their response. $86 \%$ of the marketing executives and $54 \%$ of the other executives said that the present product range of the insurance policies is enough. On the other hand $42 \%$ salesmen said that there should be more insurance policies. Thus from the response of the executives it can safely be said that the available range of insurance product is enough therefore the hypothesis can be accepted.

\section{Hypothesis 11: Level of existing insurance promotion by insurance companies is enough.}

The executives of insurance company's response on level of existing promotions are analyzed in table 16. Approximately $49 \%$ said that insurance companies need more promotions, $24 \%$ said that the existing promotion is enough and $27 \%$ said that they don't know whether the level of existing promotion is enough or not. The three groups of executives significantly differ in their response. Marketing executives and other executives completely disagree that the existing level of promotion is enough. $86 \%$ of the marketing executives and $54 \%$ of other executives said that insurance companies need more promotions, rest of them were not sure. Therefore from the given response of the executives the hypothesis 11 is rejected which says that level of existing insurance promotion by insurance companies if enough.

\subsection{Discussion}

Selling Services internationally needs the service provider to be aware of local tastes, preference and habits. However awareness alone does not suffice if the cultural distance between service provider and user is wide. To be successful, it may be necessary for both sides to undergo adaptation i.e., some changes are done to comply with local environment while locals adapt to the multinational company by accepting certain standardization (Hyder S. A., and Maria Fregidous, 2009). The concept is equally applicable to marketing insurance in Saudi Arabia. The indigenous companies operating and the multinationals intending to open insurance company in Saudi Arabia shall be complying with the Cooperative Insurance Companies Control Law. Jeannet and Hennessey (2003) observed the difficulty of persuading Japanese people to use credit cards. After years of marketing attempts, the Japanese finally appear to be accepting them.

The results in the foregoing studies suggest that the insurance in Saudi Arabia is mainly dominated by compulsory lines of business i.e., health insurance and motor insurance (see figure 1, highlights of insurance market in KSA). The fact is also supported by the secondary data which shows that $70 \%$ of the total Gross Written Premiums were contributed by health insurance and motor insurance. Approximately $75 \%$ respondents said that they purchased insurance because it is compulsory. Thus the legal factors dominate in Saudi Arabia for insurance demand (La Porta et al., 1997, 2000; Levine 1998, 1999).

Interestingly education level of the respondents significantly affected the perception of the people. It was found that those with higher degrees showed positive response for insurance and its various factors. The age of the respondents affected the perception of the people. The people significantly vary in their payment of premium, perception of the premium paid and reason for purchasing insurance. People above 40 years paid higher premium and as against the younger generations who mainly purchased insurance to comply with law, 50\% purchased insurance for their personal security.

The users of both types of insurance were by and large satisfied with the insurance policy's features and services of the insurance company. However the satisfaction level was higher among the users of health insurance compared to the users of motor insurance.

In confirmation with the previous studies (Zelizer 1979), religion has great affect on the demand of insurance services in Saudi Arabia. The entire three respondent's group viz., users of insurance, non users of insurance and the insurance executives, all agreed to the fact that one of the main resistant in accepting insurance in Saudi Arabia is that the people consider it to be against the principles of Sharia'h. Another major problem faced by the Saudi Insurance market is that though the people are by and large aware that what is insurance but they are not aware about the different types of insurance.

Figure 2 further based on the findings suggests educational promotion strategy for insurance companies in Saudi Arabia. The company shall educate the people about insurance in general, educate them about different types of 
insurance and the benefits of insurance and finally they must educate the people that insurance in Saudi Arabia is Sharia'h compliant. The companies may educate the people about the law that that mandates for every insurance company in Saudi Arabia to have Sharia'h board whose prior approval is necessary for all affairs of the insurance companies.

\section{Conclusion and Practical Implications}

From the findings it can safely be concluded that the people are not fully aware about insurance activities in Saudi Arabia. They don't know about the different types of insurance policies. The above findings suggest that public at large users as well as non users consider insurance against sharia'h despite the fact that insurance in Saudi Arabia is operating on sharia'h compliant basis. This is the reason that the main motivating factor for the people to purchase remains the legal compulsion and thus the main selling products are motor insurance and health insurance which occupy major part of the Gross Written Premium pie chart, approximately $70 \%$. The insurance executives emphasized (table 18) that fast claim settlement is the most important feature for the customers (mean 4.73, std. Deviation 0.616). The second feature was that it shall be sharia'h compliant (mean 4.65, std. Deviation 0.813) followed by simplified contract, easy procedures, high risk coverage and low premium, all these features had mean value more than 4 . Other features such as tailor made products, high discounts, easier instalment, higher return on investment and flexible terms of exit were not that important shown by mean value less than 4 .

Therefore one of the strongest challenges for the marketers of insurance shall be to educate the public that insurance in Saudi Arabia operates on cooperative basis which makes it sharia'h compliant. Hence the insurance companies needs to emphasize on educative promotional marketing strategy to spread the insurance geographically as well as to motivate the public to purchase insurance. The promotional strategy shall primarily focus on educating the people that insurance in Saudi Arabia is operating on Sharia'h compliant basis and that Saudi Arabian Monetary Agency, the regulator of the insurance companies is very serious on this issue. The insurance companies shall focus on the claim settlement process as well.

\section{Acknowledgements}

We are grateful to King Abdulaziz University, Saudi Arabia for providing us the opportunity of conducting the research, research no. 429/001-12, titled "Marketing strategies of insurance companies with reference to Saudi Arabia". We are especially thankful to the Deanship of Scientific Research for their continuous support throughout the research period.

\section{References}

Arena, M. (2008). Does Insurance Market Activity Promote Economic Growth? A Cross-Country Study for Industrialized and Developing Countries. The Journal of Risk and Insurance, 75(4): pp 921-946.

Beenstock, M. G., Dickinson, and S. Khajuria (1986). The Determination of Life Premiums: An International Cross Section Analysis 1970-81. Insuramnce Mathematics and Economics, 5: pp261-270.

Beenstock, M. G., Dickinson, and S. Khajuria (1988). The Relationship Between Property Liability Insurance Premiums and Income: An International Analysis. Journal of Risk and Insurance, 55(2): 259-272.

Ben -Arab, M., Briys, E., and Schlesinger, H. (1996). Habit Formation and the demand for insurance. Journal of Risk and Insurance, 63(1): p111-119.

Bettman, J. (1979). An Information Processing Theory of Consumer Choice. Addison - Wesley, Boston, MA.

Browne, M. J., and Kim, K. (1993). An International Analysis of Life Insurance Demand. Journal of Risk and Insurance, 60(4): pp616-34.

Cousins, P., and Stanwix, E. (2001). Its Only a Matter of Confidence! A Comparison of Relationship Management Between Japanese and UK Non Japanese Owned Motor Vehicle Manufacturers. International Journal of Operations and Production Management, Vol. 21, No.9.

Douglas, M., and A. Wildavsky (1982). Risk and culture. Berkeley University of California Press.

Elliott, M. T. (1994). An Investigation of Consumer External Information Search for Professional Services. Journal of Marketing Management, Vol. 4, No. 2, pp.8-22.

Esho, N., A. Kirievsky, D. Ward, and R. Zurbruegg (2004). Law and the Determinants of Property-Casualty Insurance. Journal of Risk and Insurance, 71(2): 265-283.

Ford, D. (2002). Understanding Business Marketing and Purchasing, Thomson Learning, Sydney. 
Hakansson, H., and Snehota, I. (2000). The IMP Perspective, Assets and Liabilities of Relationships in Sheth, J. (Ed.). Handbook of relationship Marketing, Sage, Thousand Oaks, CA.

Heaney, J., and Goldsmith, R. (1999). External Information Search for Banking Services. International Journal of Bank Marketing, Vol. 17, No.7, pp. 05-23.

Hofstead G. (1995). Insuarnce as a Product of National Values. Geneva Papers on Risk and Insurance: Issues and Practice, 20(77): 423-429.

Howard, J., and Sheth, J. (1969). The theory of Buyer Behaviour. John Wiley \& Sons Inc., New York, NY.

Hussels S., Ward D., and Zurbruegg, R. (2005). Stimulating the Demand for Insurance. Risk Management and Insurance Review, Vol. 8, No. 2, $257-278$.

Hyder, A. S., and Malama, M. F. (2009). Services Marketing in a Cross Cultural Environment: The Case of Egypt. Journal of Services Marketing, Vol. 23, pp 261-271.

Jeannet, J. P., and Hennessey, H. D. (2003). Global Marketing Strategies, $5^{\text {th }}$ ed. Houghton Miffin, Boston, MA.

La Porta, R., F. Lopez-de Silanes, A. Shleifer, and Vishny R. (1997). Legal Determinants of External Finance. Journal of Finance, 52(3): 1131 -1150.

La Porta, R., F. Lopez-de Silanes, A. Shleifer, and Vishny R. (2000). Investor Protection and Corporate Finance. Journal of Financial Economics, 58(1-2): 3-27.

Levine R. (1998). The Legal Environment, Banks, and Long-Run Economic Growth. Journal of Money, Credit and Banking, 30(3): 596-620.

Levine, R. (1999). Law, Finance and Economic Growth. Journal of Financial Intermediation, 8(12): 8-35.

Levine, R., N. Loayza, and T. Beck. (2000). Financial Intermediation and Growth: Causality and Causes. Journal of Monetary Economics, 46(1): 31-77.

Lipscomb, T., Root, T., and Shelly, K. (2004). Strategies for Seeking Mental Health Services. Services Marketing Quaterly, Vol.25, No. 4, pp. 1-12.

Mayers, D., and Smith, C. W. Jr. (1983). The Interdependence of Individual Portfolio Decisions and the Demand for Insurance. Journal of Political Economy, 91, pp304-311.

Nasco S. A., and Hale D. (2009). Information Search for Home, Medical, and Financial Services by Mature Consumers. Journal of services Marketing, 23/4: pp 226-235.

Outreville, J. F. (1996). Life Insurance Markets in Developing Countries. Journal of Risk and Insurance, 63/2: pp 263-278.

Saudi Arabian Monetary Agency - Insurance Supervision Division. (2008). The Saudi Insurance MarketReport, [Online]

Available:

http://www.sama.gov.sa/sites/SAMAEN/Insurance/InssuranceLib/4600_R_InsuaMarketSurvey2008_En_2009_0 5_16_V1.pdf (20 August 2009).

Seog, S. H. (2008). Informational Cascade in the Insurance Market. The Journal of Risk and Insurance, 75/1: pp145-165.

Showers, V., and Shotick, J. (1994). The effect of household characteristics on demand for insurance: A Tobit Analysis. Journal of Risk and Insurance, 613: pp. 492-502.

Truett, D. B., and Truett, L. J. (1990). The Demand for Life Insurance in Mexico and the United States: A Comparative Study. Journal of Risk and Insurance, 57/2: pp 321-328.

Ward, D., and Zurbruegg, R. (2002). Does Insurance Promote Economic Growth? Evidence from OECD Countries. Journal of Risk and Insurance, 67/4: pp489-507.

Wasaw, B., and Hill R. D. (1986). The Insurance Industry in Economic Development, New York: New York University Press.

Wells, B. P., and Stafford, M. R. (1995). Service Quality in the Insurance industry. Customer Perception Versus Regulatory Perceptions. Journal of Insurance Regulation, 13/4: pp.462-477.

Zelizer, V. R. (1979). Morals and Markets: The Development of Life Insurance in the United States. New York: Columbia University Press. 
Table 1. Profile of users and non users of insurance

\begin{tabular}{|l|c|c|c|c|}
\hline \multirow{2}{*}{ Profile } & \multicolumn{2}{|c|}{ Users of Insurance } & \multicolumn{2}{c|}{ Non-users of Insurance } \\
\cline { 2 - 5 } & $\mathbf{N}$ & $\mathbf{\%}$ & $\mathbf{N}$ & \% \\
\hline Age Category (year) & 400 & 80.0 & 292 & 73.0 \\
\hline $20-29$ & 86 & 17.2 & 96 & 24.0 \\
\hline $30-39$ & 14 & 2.8 & 12 & 3.0 \\
\hline $40-60$ & 500 & 100.0 & 400 & 100.0 \\
\hline Total & \multicolumn{5}{|l}{} \\
\hline Education & 239 & 47.8 & 220 & 55.0 \\
\hline High School & 62 & 12.4 & 64 & 16.0 \\
\hline Graduation & 86 & 17.2 & 38 & 9.5 \\
\hline Post Graduation & 113 & 22.6 & 78 & 19.5 \\
\hline Diploma & 500 & 100.0 & 400 & 100.0 \\
\hline Total & \multicolumn{5}{|l}{} \\
\hline
\end{tabular}

\section{USERS RESPONSE}

Table 2. Consumers' responses on purchase of health insurance products

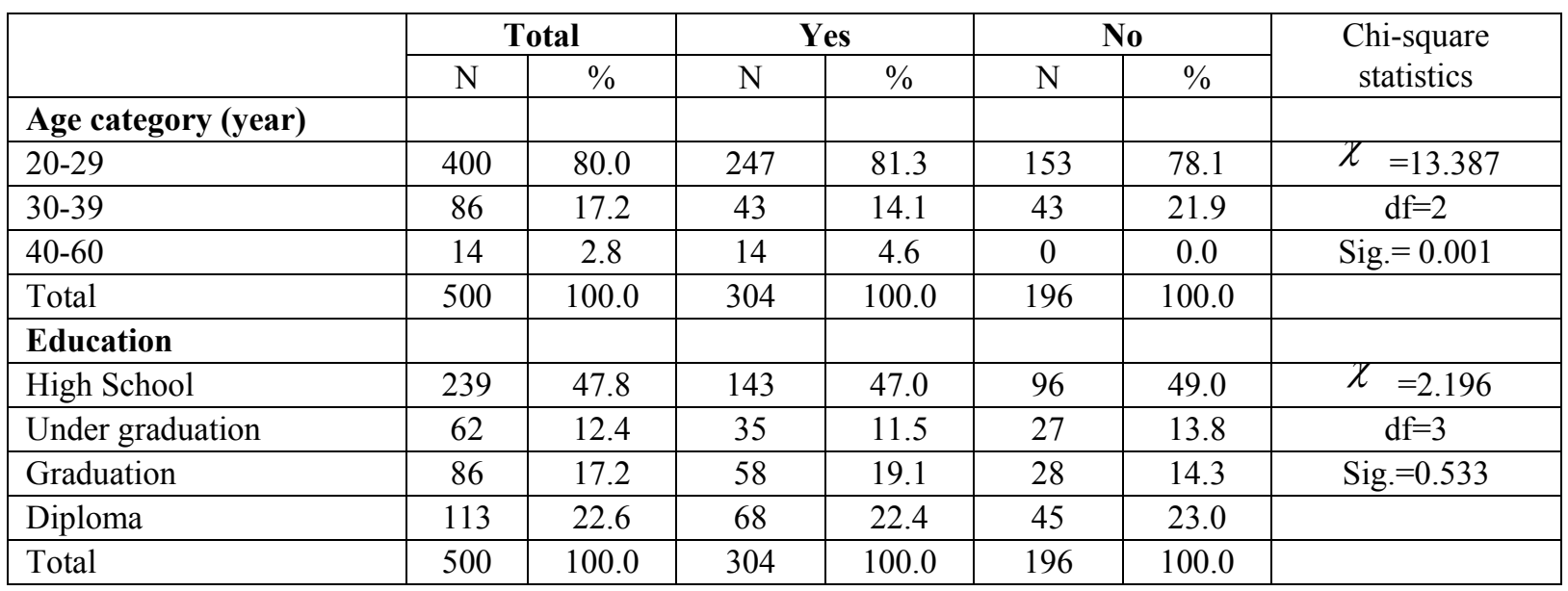

Table 3. Consumers' responses on purchase of motor insurance products

\begin{tabular}{|l|c|c|c|c|c|c|c|}
\hline \multirow{2}{*}{ Age category (year) } & \multicolumn{2}{|c|}{ Total } & \multicolumn{2}{c|}{ Yes } & \multicolumn{2}{|c|}{ No } & \multirow{2}{*}{ Chi-square statistics } \\
\cline { 2 - 7 } $20-29$ & $\mathrm{~N}$ & $\%$ & $\mathrm{~N}$ & $\%$ & $\mathrm{~N}$ & $\%$ & \\
\hline $30-39$ & & & & & & & \\
\hline $40-60$ & 800 & 80.0 & 230 & 74.7 & 170 & 88.5 & \multirow{2}{*}{$\chi^{2}=19.609$} \\
\hline Total & 14 & 2.8 & 7 & 2.3 & 7 & 3.6 & Sig. $=0.000$ \\
\hline Education & 500 & 100.0 & 308 & 100.0 & 192 & 100.0 & \\
\hline High School & & & & & & & \\
\hline Graduation & 239 & 47.8 & 109 & 35.4 & 130 & 67.7 & $\chi^{2}=54.144$ \\
\hline Post Graduation & 62 & 12.4 & 47 & 15.3 & 15 & 7.8 & $\mathrm{df}=3$ \\
\hline Diploma & 86 & 17.2 & 73 & 23.7 & 13 & 6.8 & Sig. $=0.000$ \\
\hline Total & 113 & 22.6 & 79 & 25.6 & 34 & 17.7 & \\
\hline
\end{tabular}


Table 4. Consumers' perception on different aspects of insurance products across educational categories

\begin{tabular}{|c|c|c|c|c|c|c|c|c|c|c|c|}
\hline & \multicolumn{2}{|c|}{ Total } & \multicolumn{2}{|c|}{ High School } & \multicolumn{2}{|c|}{ Graduation } & \multicolumn{2}{|c|}{$\begin{array}{c}\text { Post } \\
\text { Graduation }\end{array}$} & \multicolumn{2}{|c|}{ Diploma } & \multirow[t]{2}{*}{$\begin{array}{c}\text { Chi-square } \\
\text { statistics }\end{array}$} \\
\hline & $\mathrm{N}$ & $\%$ & $\mathrm{~N}$ & $\%$ & $\mathrm{~N}$ & $\%$ & $\mathrm{~N}$ & $\%$ & $\mathrm{~N}$ & $\%$ & \\
\hline \multicolumn{12}{|c|}{ Annual Premium } \\
\hline$<$ SR 500 & 107 & 21.4 & 63 & 26.4 & 10 & 16.1 & 24 & 27.9 & 10 & 8.8 & $\chi^{2}=214.729$ \\
\hline $\begin{array}{l}\text { SR } 500- \\
\text { SR } 999\end{array}$ & 166 & 33.2 & 97 & 40.6 & 6 & 9.7 & 0 & 0.0 & 63 & 55.8 & $\mathrm{Df}=15$ \\
\hline $\begin{array}{l}\text { SR 1000- } \\
\text { SR } 1999\end{array}$ & 129 & 25.8 & 69 & 28.9 & 17 & 27.4 & 24 & 27.9 & 19 & 16.8 & Sig. $=0.000$ \\
\hline $\begin{array}{l}\text { SR } 2000- \\
\text { SR } 2999\end{array}$ & 65 & 13.0 & 0 & 0.0 & 16 & 25.8 & 28 & 32.6 & 21 & 18.6 & \\
\hline $\begin{array}{l}\text { SR } 3000- \\
\text { SR } 4999\end{array}$ & 20 & 4.0 & 0 & 0.0 & 13 & 21.0 & 7 & 8.1 & 0 & 0.0 & \\
\hline$>$ SR 5000 & 13 & 2.6 & 10 & 4.2 & 0 & 0.0 & 3 & 3.5 & 0 & 0.0 & \\
\hline Total & 500 & 100 & 239 & 100.0 & 62 & 100.0 & 86 & 100.0 & 113 & 100.0 & \\
\hline \multicolumn{12}{|c|}{ Perception on Premium } \\
\hline Low & 66 & 13.2 & 53 & 22.2 & 10 & 16.1 & 0 & 0.0 & 3 & 2.7 & $\chi^{2}=93.957$ \\
\hline Medium & 231 & 46.2 & 89 & 37.2 & 43 & 69.4 & 62 & 72.1 & 37 & 32.7 & $\mathrm{df}=6$ \\
\hline High & 203 & 40.6 & 97 & 40.6 & 9 & 14.5 & 24 & 27.9 & 73 & 64.6 & Sig. $=0.000$ \\
\hline Total & 500 & 100 & 239 & 100 & 62 & 100 & 86 & 100 & 113 & 100 & \\
\hline \multicolumn{12}{|c|}{ Reason for Purchase } \\
\hline $\begin{array}{l}\text { Legal } \\
\text { Compulsion }\end{array}$ & 377 & 75.4 & 177 & 74.1 & 31 & 50.0 & 66 & 76.7 & 103 & 91.2 & $\chi^{2}=57.904$ \\
\hline $\begin{array}{l}\text { Personal } \\
\text { Security }\end{array}$ & 114 & 22.8 & 59 & 24.7 & 25 & 40.3 & 20 & 23.3 & 10 & 8.8 & $\mathrm{df}=9$ \\
\hline $\begin{array}{l}\text { Security of } \\
\text { Family }\end{array}$ & 6 & 1.2 & 3 & 1.3 & 3 & 4.8 & 0 & 0.0 & 0 & 0.0 & Sig. $=0.000$ \\
\hline $\begin{array}{l}\text { Good Return } \\
\text { on Investment }\end{array}$ & 3 & 0.6 & 0 & 0.0 & 3 & 4.8 & 0 & 0.0 & 0 & 0.0 & \\
\hline Total & 500 & 100 & 239 & 100 & 62 & 100 & 86 & 100 & 113 & 100 & \\
\hline \multicolumn{12}{|c|}{ Source of Purchase } \\
\hline $\begin{array}{l}\text { Direct } \\
\text { Company }\end{array}$ & 416 & 83.2 & 190 & 79.5 & 50 & 80.6 & 72 & 83.7 & 104 & 92.0 & $\chi^{2}=55.932$ \\
\hline $\begin{array}{l}\text { Company } \\
\text { Sales Person }\end{array}$ & 45 & 9.0 & 19 & 7.9 & 9 & 14.5 & 14 & 16.3 & 3 & 2.7 & $\mathrm{df}=9$ \\
\hline Brokers & 36 & 7.2 & 30 & 12.6 & 0 & 0.0 & 0 & 0.0 & 6 & 5.3 & Sig. $=0.000$ \\
\hline $\begin{array}{l}\text { Insurance } \\
\text { Agencies }\end{array}$ & 3 & 0.6 & 0 & 0.0 & 3 & 4.8 & 0 & 0.0 & 0 & 0.0 & \\
\hline Total & 500 & 100 & 239 & 100 & 62 & 100 & 86 & 100 & 113 & 100 & \\
\hline \multicolumn{12}{|c|}{ Level of Risk coverage } \\
\hline Full & 284 & 56.8 & 124 & 51.9 & 43 & 69.4 & 69 & 80.2 & 48 & 42.5 & $\chi^{2}=53.974$ \\
\hline Partial & 199 & 39.8 & 112 & 46.9 & 19 & 30.6 & 10 & 11.6 & 58 & 51.3 & $\mathrm{df}=6$ \\
\hline Conditional & 17 & 3.4 & 3 & 1.3 & 0 & 0.0 & 7 & 8.1 & 7 & 6.2 & Sig. $=0.000$ \\
\hline Total & 500 & 100 & 239 & 100 & 62 & 100 & 86 & 100 & 113 & 100 & \\
\hline
\end{tabular}


Table 5. Consumers' perception on different aspects of insurance products across age categories

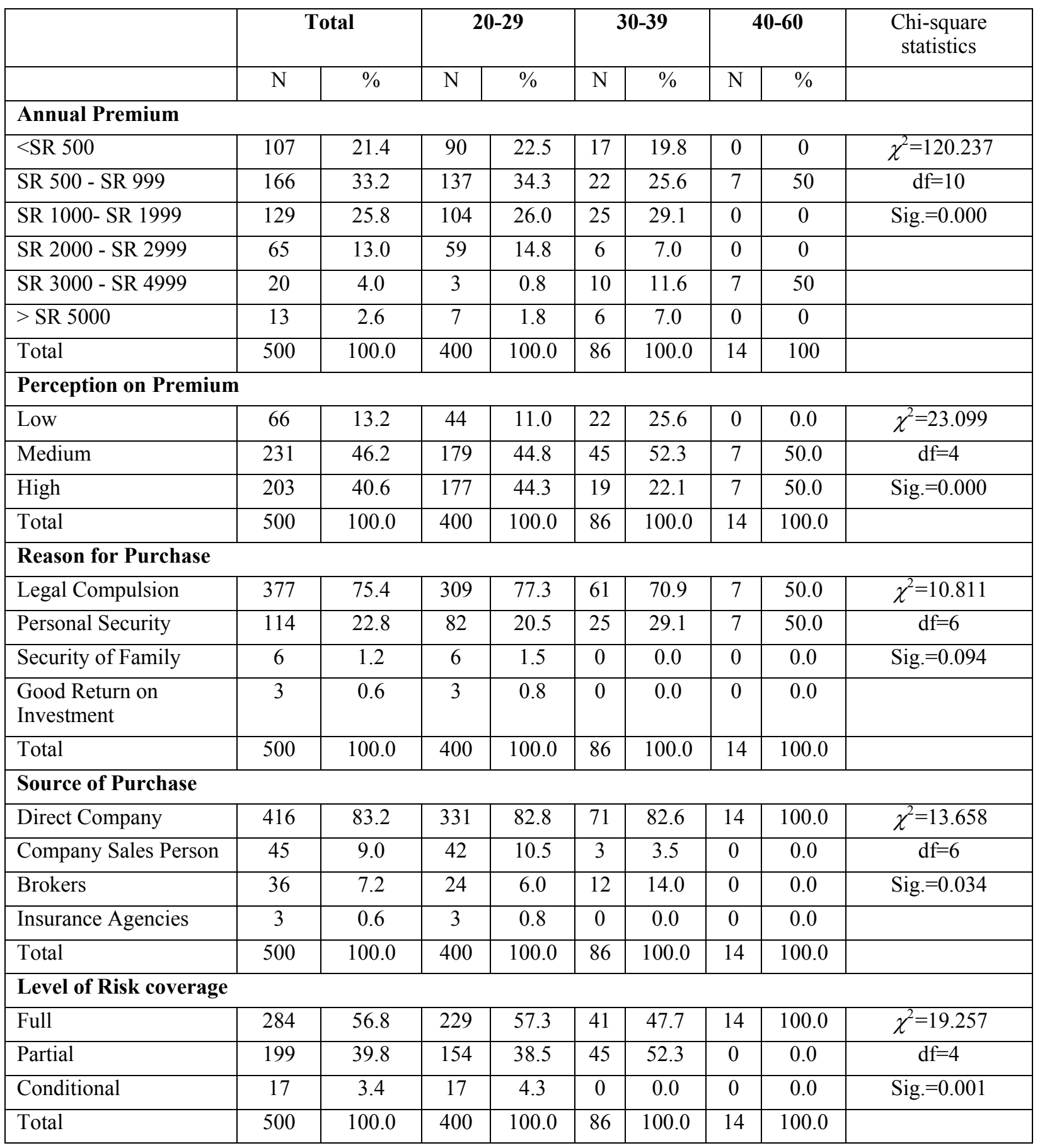


Table 6. Factor Analysis - Rotated Component Matrix

\begin{tabular}{|l|c|c|}
\hline Product Features & \multicolumn{2}{|c|}{ Component } \\
\cline { 2 - 3 } & $\mathbf{I}$ & $\mathbf{2}$ \\
\hline High Risk Coverage & 0.797 & 0.242 \\
\hline Fast claims Settlement & 0.797 & 0.296 \\
\hline Simplified Contract & 0.788 & 0.213 \\
\hline Tailor Made Products & 0.787 & 0.055 \\
\hline Ease of Procedures & 0.746 & 0.145 \\
\hline Easier Instalment & 0.667 & 0.441 \\
\hline Low Premium & 0.554 & 0.475 \\
\hline Legally Safe & 0.548 & 0.296 \\
\hline Higher Return on Investment & 0.027 & 0.784 \\
\hline Flexible Terms of Exit & 0.297 & 0.768 \\
\hline High Discount & 0.316 & 0.730 \\
\hline Total variance explained (\%) & 39.168 & 22.369 \\
\hline Cumulative variance explained (\%) & 39.168 & 61.537 \\
\hline Extraction Method: Principal Component Analysis. Rotation Method: Varimax with Kaiser Normalization. \\
\hline
\end{tabular}

Table 7. Cluster Membership (Hierarchical cluster)

\begin{tabular}{|l|c|}
\hline Case & 2 Clusters \\
\hline Higher Return on Investment & 1 \\
\hline Easier Instalments & 2 \\
\hline Flexible Terms of Exit & 2 \\
\hline Low Premium & 2 \\
\hline High Discount & 2 \\
\hline High Risk Coverage & 2 \\
\hline Legally Safe & 2 \\
\hline Ease of Procedures & 2 \\
\hline Fast claims Settlement & 2 \\
\hline Tailor Made Products & 2 \\
\hline Simplified Contract & 2 \\
\hline
\end{tabular}

Table 8. Number of Cases in each Cluster (K-means cluster)

\begin{tabular}{|l|c|c|c|}
\hline Cluster & 1 & 387 & $77.4 \%$ \\
\hline & 2 & 113 & $22.6 \%$ \\
\hline Total cases & & 500 & 100.00 \\
\hline
\end{tabular}

Table 9. Satisfaction level of users

\begin{tabular}{|l|c|c|c|c|}
\hline & \multicolumn{2}{|c|}{ Motor insurance } & \multicolumn{2}{c|}{ Health insurance } \\
\hline & Mean & SD & Mean & SD \\
\hline Product Features & 1.79 & 0.976 & 1.58 & 0.828 \\
\hline Procedures of Purchasing Insurance & 2.06 & 1.135 & 1.97 & 0.964 \\
\hline Risk Coverage & 2.08 & 1.087 & 1.60 & 0.734 \\
\hline Payment of Premium & 2.10 & 1.104 & 1.90 & 0.908 \\
\hline Premium Rate & 2.18 & 1.043 & 1.75 & 0.726 \\
\hline Level of Hidden Information & 2.22 & 1.241 & 2.06 & 1.130 \\
\hline Claim Settlement Procedure & 2.46 & 1.264 & 2.17 & 1.308 \\
\hline Promotion and Discount & 2.49 & 1.275 & 2.25 & 1.186 \\
\hline *highly satisfy-1,..,highly dis-satisfied-5 & \multicolumn{4}{l}{} \\
\hline
\end{tabular}


Table 10. Focus of promotions of the insurance company

\begin{tabular}{|l|c|c|c|c|}
\hline \multirow{2}{*}{} & \multicolumn{2}{|c|}{ Users } & \multicolumn{2}{c|}{ Executives } \\
\cline { 2 - 5 } & Mean & SD & Mean & SD \\
\hline Educate that Insurance in Saudi Arabia is Sharia'h Compliant & 1.26 & 0.439 & 1.73 & 0.449 \\
\hline Educating About Benefits of Insurance & 1.29 & 0.455 & 1.34 & 0.476 \\
\hline Educating About Insurance Products & 1.31 & 0.463 & 1.56 & 0.499 \\
\hline Focus on Premium & 1.40 & 0.490 & 1.81 & 0.393 \\
\hline Inform About the Easy Procedure & 1.66 & 0.474 & 1.96 & 0.191 \\
\hline Information About Company & 1.85 & 0.353 & 1.75 & 0.436 \\
\hline *Yes-1, no-2 & \multicolumn{4}{|l|}{} \\
\hline
\end{tabular}

Table 11. Issues in respect to insurance

\begin{tabular}{|l|c|c|}
\hline Issues & \multicolumn{2}{|c|}{ Users } \\
\hline & Mean & SD \\
\hline People consider Insurance against Sharia'h & 1.67 & 1.128 \\
\hline People Want Lower Premium & 1.67 & 1.053 \\
\hline People Want More Features in Insurance & 1.88 & 1.063 \\
\hline People Do Not Know About Different Insurance Products & 2.09 & 1.283 \\
\hline People Avoid Insurance Salesman & 2.23 & 1.291 \\
\hline People Do Not Show Interest in Insurance & 2.34 & 1.334 \\
\hline People consider buying insurance as waste of money & 2.38 & 1.376 \\
\hline People Do Not Know About Insurance & 2.45 & 1.739 \\
\hline *highly agree-1,..,highly disagree-5 & & \\
\hline
\end{tabular}

\section{NON USERS RESPONSE}

Table 12.

\begin{tabular}{|l|c|c|c|c|}
\hline Reason for not purchasing insurance & N & Mean* & Mode & Std. Deviation \\
\hline Insurance is Against Sharia'h & 400 & 1.54 & 2 & 0.499 \\
\hline No Reason In fact I May Buy it Later & 400 & 1.54 & 2 & 0.499 \\
\hline I am Aware But I don't Need & 400 & 1.64 & 2 & 0.482 \\
\hline No one has Communicated About Insurance & 400 & 1.66 & 2 & 0.476 \\
\hline $\begin{array}{l}\text { I don't Have Any Such Asset Where Insurance is } \\
\text { Compulsory }\end{array}$ & 400 & 1.66 & 2 & 0.474 \\
\hline I Don't Have Insurable Interest & 400 & 1.71 & 2 & 0.454 \\
\hline Not Fully Aware of Insurance Plans & 400 & 1.72 & 2 & 0.450 \\
\hline $\begin{array}{l}\text { I Have Better Means of Investment That Gives higher } \\
\text { Returns }\end{array}$ & 400 & 1.78 & 2 & 0.415 \\
\hline 1-yes, no-2 & & & \\
\hline
\end{tabular}

Table 13. Ideal insurance plan

\begin{tabular}{|l|c|c|c|c|}
\hline Features & $\mathbf{N}$ & Mean $^{*}$ & Mode & Std. Deviation \\
\hline Legally and Morally Safe & 400 & 1.33 & 1 & 0.642 \\
\hline Sharia'h Compliant & 400 & 1.39 & 1 & 0.606 \\
\hline Ease of Procedures & 400 & 1.70 & 1 & 0.729 \\
\hline High Return on Investment & 400 & 1.83 & 1 & 0.810 \\
\hline Flexible Terms of Exit & 400 & 1.86 & 1 & 0.838 \\
\hline Moderate But Consistent Income & 400 & 1.87 & 1 & 0.780 \\
\hline *very important-1, ..., important-3 & \multicolumn{5}{|l}{} \\
\hline
\end{tabular}




\section{INSURANCE EXECUTIVES RESPONSE}

Table 14. Reason for purchase of insurance

\begin{tabular}{|c|c|c|c|c|c|c|c|c|c|c|}
\hline \multirow[t]{2}{*}{$\begin{array}{l}\text { Reason for purchase } \\
\text { insurance products }\end{array}$} & \multicolumn{2}{|c|}{ Salesman } & \multicolumn{2}{|c|}{$\begin{array}{l}\text { Marketing } \\
\text { Executive }\end{array}$} & \multicolumn{2}{|c|}{$\begin{array}{c}\text { Other } \\
\text { Executives }\end{array}$} & \multicolumn{2}{|c|}{ Total } & \multirow[t]{2}{*}{$\mathbf{F}$} & \multirow[t]{2}{*}{ Sig. } \\
\hline & $\begin{array}{c}\text { Mean } \\
*\end{array}$ & SD & Mean & SD & Mean & SD & Mean & SD & & \\
\hline Legal Compulsion & 1.11 & 0.32 & 1.00 & 0.00 & 1.13 & 0.34 & 1.09 & 0.28 & 1.371 & 0.260 \\
\hline Personal Security & 1.23 & 0.43 & 1.29 & 0.46 & 1.50 & 0.51 & 1.33 & 0.47 & 2.557 & 0.084 \\
\hline $\begin{array}{l}\text { General safety of } \\
\text { Goods/Business }\end{array}$ & 1.54 & 0.51 & 1.10 & 0.30 & 1.50 & 0.51 & 1.41 & 0.50 & 6.751 & 0.002 \\
\hline Security of Family & 1.34 & 0.48 & 1.57 & 0.51 & 1.63 & 0.49 & 1.49 & 0.50 & 2.753 & 0.070 \\
\hline $\begin{array}{l}\text { Safe Means of } \\
\text { Investment }\end{array}$ & 2.00 & 0.00 & 2.00 & 0.00 & 2.00 & 0.00 & 2.00 & 0.00 & & \\
\hline $\begin{array}{l}\text { Good Return on } \\
\text { Investment }\end{array}$ & 2.00 & 0.00 & 2.00 & 0.00 & 2.00 & 0.00 & 2.00 & 0.00 & & \\
\hline
\end{tabular}

Table 15. Present product range

\begin{tabular}{|l|c|c|c|c|c|c|c|c|c|c|}
\hline & \multicolumn{2}{|c|}{ Total } & \multicolumn{2}{c|}{ Salesman } & \multicolumn{2}{c|}{$\begin{array}{c}\text { Marketing } \\
\text { Executive }\end{array}$} & \multicolumn{2}{c|}{$\begin{array}{c}\text { Other } \\
\text { Executives }\end{array}$} & $\begin{array}{c}\text { Chi-square } \\
\text { statistics }\end{array}$ \\
\hline & $\mathrm{N}$ & $\%$ & $\mathrm{~N}$ & $\%$ & $\mathrm{~N}$ & $\%$ & $\mathrm{~N}$ & $\%$ & \\
\hline \multicolumn{8}{|c|}{ Product Range } \\
\hline Enough & 43 & 53.8 & 12 & 34.3 & 18 & 85.7 & 13 & 54.2 & $\chi=15.068$ \\
\hline Needs more product & 26 & 32.5 & 15 & 42.9 & 2 & 9.5 & 9 & 37.5 & $\mathrm{df}=4$ \\
\hline Not Sure & 11 & 13.8 & 8 & 22.9 & 1 & 4.8 & 2 & 8.3 & Sig. $=.005$ \\
\hline Total & 80 & 100.0 & 35 & 100.0 & 21 & 100.0 & 24 & 100.0 & \\
\hline
\end{tabular}

Table 16. Level of existing promotion

\begin{tabular}{|l|c|c|c|c|c|c|c|c|c|}
\hline & \multicolumn{2}{|c|}{ Total } & \multicolumn{2}{c|}{ Salesman } & \multicolumn{2}{c|}{$\begin{array}{c}\text { Marketing } \\
\text { executives }\end{array}$} & \multicolumn{2}{c|}{$\begin{array}{c}\text { Other } \\
\text { executives }\end{array}$} & $\begin{array}{c}\text { Chi-Square } \\
\text { statistics }\end{array}$ \\
\hline Promotional Activity & $\mathrm{N}$ & $\%$ & $\mathrm{~N}$ & $\%$ & $\mathrm{~N}$ & $\%$ & $\mathrm{~N}$ & $\%$ & \\
\hline Enough & 19 & 23.75 & 19 & 54.3 & 0 & 0 & 0 & 0 & $\chi=39.813$ \\
\hline Needs More Promotions & 39 & 48.75 & 8 & 22.9 & 18 & 85.7 & 13 & 54.2 & $\mathrm{df}=4$ \\
\hline Don't Know & 22 & 27.5 & 8 & 22.9 & 3 & 14.3 & 11 & 45.8 & Sig. $=0.000$ \\
\hline Total & 80 & 100 & 35 & 100.0 & 21 & 100 & 24 & 100 & \\
\hline
\end{tabular}


Table 17. Problems of marketing insurance

\begin{tabular}{|c|c|c|c|c|c|c|c|c|c|c|}
\hline & \multicolumn{2}{|c|}{ Salesman } & \multicolumn{2}{|c|}{$\begin{array}{l}\text { Marketing } \\
\text { Executive }\end{array}$} & \multicolumn{2}{|c|}{$\begin{array}{c}\text { Other } \\
\text { Executives }\end{array}$} & \multicolumn{2}{|c|}{ Total } & \multirow[t]{2}{*}{$\mathbf{F}$} & \multirow[t]{2}{*}{ Sig. } \\
\hline & Mean* & SD & Mean & SD & Mean & SD & Mean & SD & & \\
\hline \multicolumn{11}{|c|}{ Specific problems faced in field while marketing insurance } \\
\hline $\begin{array}{l}\text { They don't know } \\
\text { about different } \\
\text { insurance products }\end{array}$ & 1.34 & 0.482 & 1.29 & 0.463 & 1.08 & 0.282 & 1.25 & 0.436 & 2.736 & 0.071 \\
\hline $\begin{array}{l}\text { They consider } \\
\text { insurance haraam }\end{array}$ & 1.43 & 0.502 & 1.19 & 0.402 & 1.17 & 0.381 & 1.29 & 0.455 & 3.164 & 0.048 \\
\hline $\begin{array}{l}\text { People do not } \\
\text { know about } \\
\text { insurance }\end{array}$ & 1.34 & 0.482 & 1.29 & 0.463 & 1.25 & 0.442 & 1.30 & 0.461 & 0.297 & 0.744 \\
\hline $\begin{array}{l}\text { People avoid } \\
\text { insurance salesman }\end{array}$ & 1.34 & 0.482 & 1.67 & 0.483 & 1.38 & 0.495 & 1.44 & 0.499 & 3.198 & 0.046 \\
\hline $\begin{array}{l}\text { They do not show } \\
\text { interest in } \\
\text { insurance }\end{array}$ & 1.77 & 0.426 & 1.29 & 0.463 & 1.25 & 0.442 & 1.49 & 0.503 & 12.948 & 0.000 \\
\hline $\begin{array}{l}\text { They want lower } \\
\text { premium }\end{array}$ & 1.89 & 0.323 & 1.24 & 0.436 & 1.54 & 0.509 & 1.61 & 0.490 & 16.420 & 0.000 \\
\hline $\begin{array}{l}\text { They consider } \\
\text { buying insurance } \\
\text { as waste of money }\end{array}$ & 1.89 & 0.323 & 1.24 & 0.436 & 1.67 & 0.482 & 1.65 & 0.480 & 16.735 & 0.000 \\
\hline $\begin{array}{l}\text { They want more } \\
\text { features in } \\
\text { insurance }\end{array}$ & 1.91 & 0.284 & 1.52 & 0.512 & 1.79 & 0.415 & 1.78 & 0.420 & 6.484 & 0.002 \\
\hline $\begin{array}{l}\text { Long waiting } \\
\text { hours for talking to } \\
\text { managers in } \\
\text { companies }\end{array}$ & 2.00 & 0.000 & 1.52 & 0.512 & 1.92 & 0.282 & 1.85 & 0.359 & 17.033 & 0.000 \\
\hline $\begin{array}{l}\text { People are not } \\
\text { easily available }\end{array}$ & 1.80 & 0.406 & 2.00 & 0.000 & 1.83 & 0.381 & 1.86 & 0.347 & 2.388 & 0.099 \\
\hline
\end{tabular}

Table 18. Preferred features in insurance plan from a customer's point of view

\begin{tabular}{|l|c|c|c|c|c|c|c|c|c|c|}
\hline $\begin{array}{l}\text { Important features } \\
\text { of an insurance plan } \\
\text { from a customer's } \\
\text { point of view }\end{array}$ & \multicolumn{2}{|c|}{ Salesman } & \multicolumn{2}{|c|}{$\begin{array}{c}\text { Marketing } \\
\text { Executive }\end{array}$} & \multicolumn{2}{|c|}{$\begin{array}{c}\text { Other } \\
\text { Executives }\end{array}$} & \multicolumn{2}{|c|}{ Total } & \multirow{2}{*}{ Sig. } \\
\cline { 2 - 11 } & Mean* & SD & Mean & SD & Mean & SD & Mean & SD & & \\
\hline $\begin{array}{l}\text { Fast Claims } \\
\text { Settlements }\end{array}$ & 4.49 & 0.818 & 5.00 & 0.000 & 4.83 & 0.381 & 4.73 & 0.616 & 5.719 & 0.005 \\
\hline Legally Safe & 4.91 & 0.284 & 4.48 & 0.981 & 4.42 & 1.060 & 4.65 & 0.813 & 3.531 & 0.034 \\
\hline Simplified Contract & 4.31 & 0.832 & 4.90 & 0.301 & 4.75 & 0.442 & 4.60 & 0.668 & 6.897 & 0.002 \\
\hline Ease of Procedures & 4.46 & 0.852 & 4.43 & 0.811 & 4.58 & 0.504 & 4.49 & 0.746 & 0.287 & 0.751 \\
\hline High Risk Coverage & 4.66 & 0.968 & 4.24 & 0.889 & 4.08 & 0.776 & 4.38 & 0.919 & 3.267 & 0.043 \\
\hline Low Premium & 3.57 & 1.092 & 4.62 & 0.805 & 4.58 & 0.504 & 4.15 & 1.008 & 13.519 & 0.000 \\
\hline Tailor Made Products & 3.66 & 0.838 & 3.95 & 1.161 & 4.42 & 1.060 & 3.96 & 1.037 & 4.126 & 0.020 \\
\hline High Discount & 3.49 & 1.173 & 4.14 & 0.854 & 4.33 & 0.637 & 3.91 & 1.021 & 6.398 & 0.003 \\
\hline Easier Installment & 4.09 & 1.483 & 3.14 & 1.014 & 3.67 & 1.274 & 3.71 & 1.352 & 3.407 & 0.038 \\
\hline $\begin{array}{l}\text { Higher Return on } \\
\text { Investment }\end{array}$ & 3.63 & 1.165 & 3.24 & 1.446 & 3.50 & 1.642 & 3.49 & 1.387 & 0.515 & 0.599 \\
\hline Flexible terms of exit & 3.86 & 1.115 & 2.81 & 0.402 & 3.33 & 0.761 & 3.43 & 0.965 & 9.611 & 0.000 \\
\hline *not imp. at all-1,..., most imp.-5
\end{tabular}




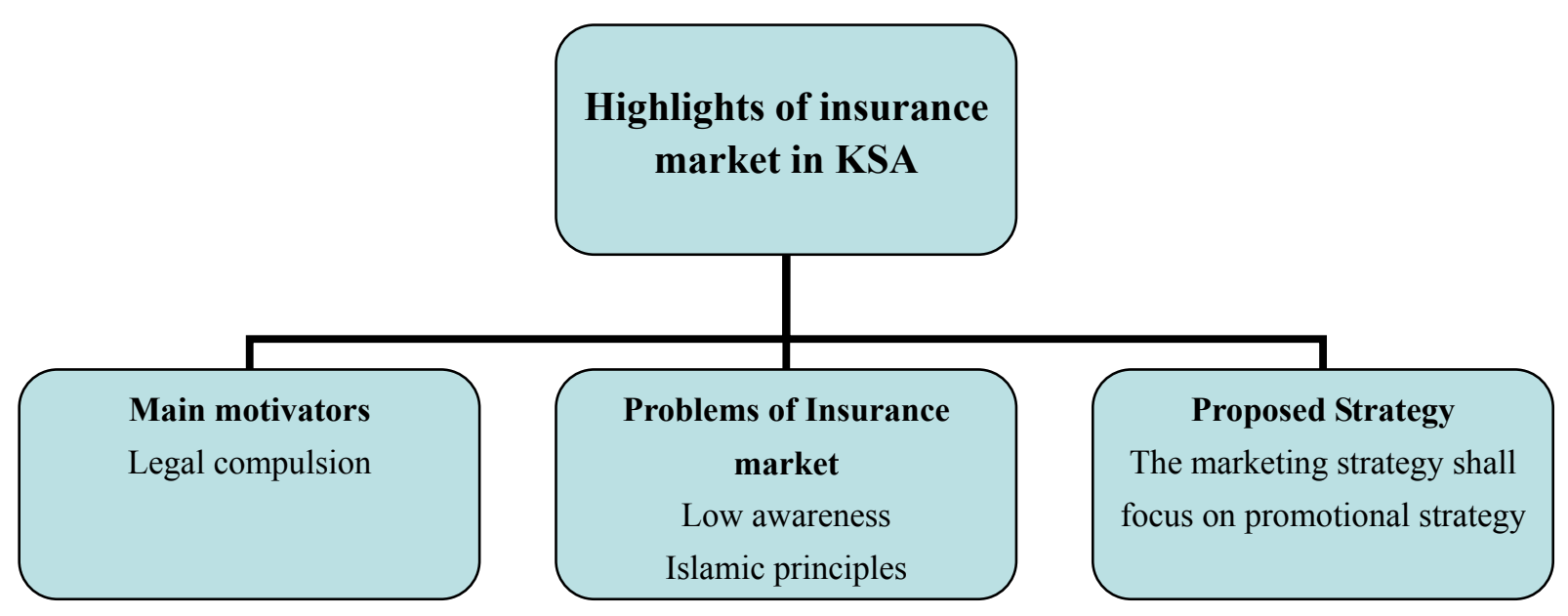

Figure 1

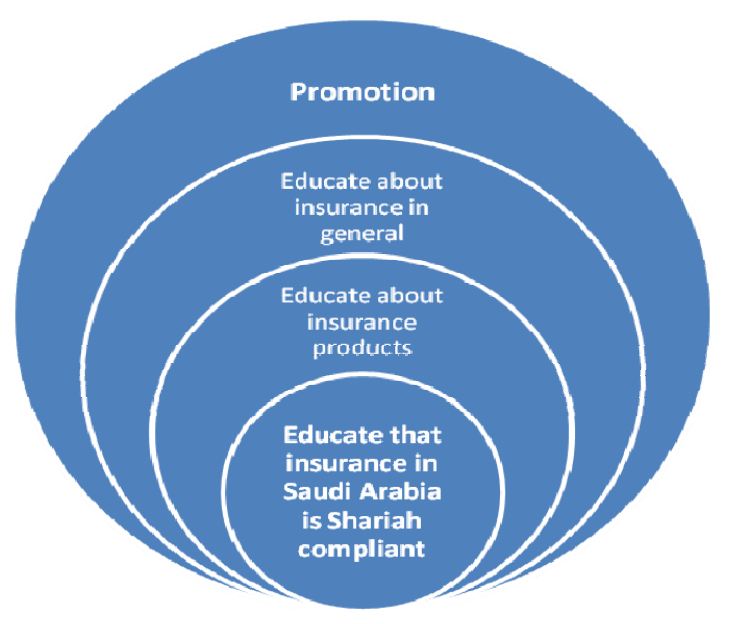

Figure 2 